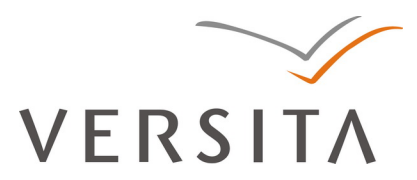

DOI: 10.2478/genst-2013-0016

\title{
ANTI-ANTIFEMINISM IN CHAUCER'S THE CANTERBURY TALES
}

\author{
ELISABETA ZELINKA \\ West University of Timișoara \\ 4, Pârvan Street, Timişoara, Romania \\ elisabeta_zelinka@yahoo.com
}

\begin{abstract}
A characteristic of the medieval fabliaux is the dogma of antifeminist traditions. The present article will investigate whether The Canterbury Tales, as a type of fabliaux, are antifeminist literature or if, on the contrary, they stand as a reply to this genre and indirectly militate for feminist literature. Are The Canterbury Tales antifeminist writings or something one might call 'anti-antifeminist' literature?
\end{abstract}

Key words: Christian etiquette in the Middle Ages, fabliaux, female dominance in marriage, natural lifestyle, romance.

\section{Introduction}

"A characteristic of Medieval Latin writing that is widely exploited in the fabliaux [...] is the dogma of antifeminist traditions: traditions which present women, the daughters of Eve, as generally morally reprehensible and dangerous to men: insatiable and extravagant sexual sirens, [...] perjurers, temptresses or endless naggers with their tongues" (Hines 1993:31). This is 
what John Hines argues in his book The Fabliau in English, adding that Chaucer's fabliaux in The Canterbury Tales are samples of the aforementioned type of antifeminist literature. The best examples would be The Miller's Tale, The Prologue of the Wife of Bath's Tale and The Wife of Bath's Tale. It must be noted that although the Wife's Tale is not a fabliau but a romance, her Prologue is nevertheless considered to be a typical fabliau (Benson 1997:11).

Hines' argument does not pay sufficient attention to one key element in these three literary pieces: in each of them, Chaucer indeed presents his female characters as sexual 'sirens', and sometimes he even adds a touch of cruelty and vulgarity to their portraits. It is also true that Chaucer turns the outcome of their adulterous or hedonistic acts to the advantage of these conspicuous women. In spite of their unorthodox Weltanschauung and modus vivendi, he still presents them as winners, prevailers over their husbands in their battle of the sexes. That is why, paradoxical as it may seem, the medieval poet indirectly praises these devilish, nymphomaniac female characters.

Following this line of thought, an epicentral question arises: are The Canterbury Tales a piece of antifeminist literature, in line with what John Hines states about fabliaux, or, on the contrary, do they stand as a response to this genre and indirectly militate for feminist literature? Are The Canterbury Tales antifeminist literature or something one might call 'anti-antifeminist' literature?

\section{Body: Sly and Adulterous Female Personages}

If we consider The Miller's Tale, Alison, the young, sensual and beautiful wife cheats on her foolish old husband John. She also makes vulgar and merciless fun of Absalom, her over-fastidious admirer, in the scene of the 
misplaced kiss. Finally, Nicholas, her lover, is branded by the jealous Absalom, while the latter endures a threefold humiliation: first Alison openly mocks him while he is singing a love song in the middle of the night, secondly he endures the scene of the misplaced kiss and lastly he is forced to witness Nicholas' flatulence.

Beyond any doubt, husband, lover and admirer all endure their fair share of humiliation and physical pain. Each of them has to undergo suffering except the one who is the real sinner: Alison, the adulterous, cruel and vulgar wife. Although she is the one causing trouble to each of them and is the source of evil, nevertheless she is the only one who is not punished by Chaucer in any way. What is more, she emerges as the only character in her group who thoroughly enjoys this adventure and comes out scot-free, as the sole victor.

Following Alison, the Wife of Bath is a second example for Chaucer's positionality regarding his evil female characters: she embodies hedonism, an easy-going carelessness ("Since I twelve year was of age, / [...] Husbands at the church door have I had five", Chaucer 2000:142), sexuality taken to vulgarity or even to perversity ("But of no number mention made he, / Of bigamy or of octogamy; / Why then should men speak of it villainy?" (142); "In wifehood I will use mine instrument / As freely as my Maker hath it sent" (144) and, above all, female dominance in marriage ("Which shall be both my debtor and my thrall, / And have his tribulation withal / Upon his flesh, while that I am his wife. / I have the power during all my life / Upon his proper body, and not he" (144).

What is more, in the same way as Alison does, the Wife of Bath also takes full advantage of the men in her life: she is the only one who fully enjoys 
her adventures and the sole victor as well. By exploiting all her five husbands to the maximum, she receives material profit from them and sexual pleasure too: "They had me giv'n their land and their treasor, of no account / Me needed not do longer diligence / To win their love, or do them reverence. / They loved me so well, by God above, / That I tolde no dainty of their love. / A wise woman will busy her ever-in-one / To get their love, where that she hath none. / But, since I had them wholly in my hand, / And that they had me given all their land, / Why should I keep them for to please, / But it were for my profit, or mine ease?" (145).

Lastly, we scarcely need mention that dominance in her marriages is hers as well. These are the three main gains she extorts from her pitiful husbands and the three paramount pillars of her existence.

\section{Promoting Novelty and the Natural: Female versus Male Characters.}

Why should Chaucer have praised his adulterous, vulgar female characters and made them into the victors of his Tales, thus showing them indirect or veiled appreciation? As proves to be the case, the Tales are not antifeminist literature but in fact anti-antifeminist literature, that is, veiled praise of womanhood. They function "as a kind of interface between readings from antifeminism and responses to antifeminism" and the Wife of Bath's part becomes an up-front reply to medieval antifeminist literature (Blamires 1992:198). Yet my epicentral question craves an answer: why does Chaucer choose to praise this type of female characters, who are, morally speaking, fallen, putrid, decayed? Why does he offer them auctorial salvation, especially considering the fact that he was living in the Middle Ages, when the 
intransigent Christian moral code was omnipotent and unequivocally castigated such (female sexual) behavior? Why does the poet choose to take the risk of confronting the Church?

The most unambiguous answer to this question is an element that these two female characters share, their metaphorical common denominator: their enviable vital force, their effervescent existential vigor, their exuberance for life as a very simple, yet natural and grand celebration. Their modus vivendi and modus operandi presuppose a quite simple yet natural philosophy: living life in a very sprightly but at the same time in a hedonistic way, enjoying every moment of life and of men's weakness, without ever suffering from feelings of apprehension. They enjoy life's (and men's) spontaneous gifts, basing all their conduct on their own instinctive and passionate decisions, and they place their personal, feminine wellbeing above all social, moral and religious Procrustean matrices.

I will mention in this context the portrait we are given of Alison in The Miller's Tale, which suggests her close connection with Nature and with a thoroughly natural lifestyle, as it contains numerous associations with natural elements: "Fair was this younge wife, and therewithal / As any weasel her body gent and small / A seint she weared, barred all of silk, / A barm-cloth eke as white as morning milk / Upon her lendes, full of many a gore / White was her smock, and broider'd all before, / And eke behind, on her collar about / Of coalblack silk, within and eke without" (89); "But of her song, it was as loud and lively / As any swallow chittering on a barn / As any kid or calf following his dame. / Her mouth was sweet as braket, or as mead / Or hoard of apples, laid in hay or heath. / Wincing she was as is a jolly colt" (90). 
She seems to be part of Nature herself and therefore she has no sophisticated existence such as that of her lover Nicholas, the scholar. Alison only enjoys human life within an unaffected, genuine, instinctual framework, based on her feminine and gender-specific impulses, wit and presence of mind. At the other end of the spectrum, Nicholas represents masculinity-associated (yet sterile) reason. He is the perfect bookworm, who lives life according to the books he reads and to what he deciphers from the stars, since he is an astrologer

As a visionary of his age, Chaucer appears to be announcing the imminent twilight of the Middle Ages, by constantly castigating the unnatural, old-fashioned, inflexible (male) characters who seem to be prisoners of the previous age. On the other hand he promotes his natural, ingenious (female) personages, the only ones who dare challenge the obsolete etiquette of the past in an avant-garde fashion.

Alison's vivacious lifestyle is also opposed to that of her husband, whom Chaucer portrays as a cuckolded and jealous elderly husband. He is clearly presented as ridiculous as he constantly acts against the laws of nature and against natural impulses, by imprisoning his beautiful young wife in a golden cage out of fear that she may cheat on him. He therefore figures as a stubborn opponent of women's freedom and of the laws of natural attraction, while Chaucer constantly argues in favor of a natural lifestyle, both bodily and spiritually. This is why Chaucer does not chastise Alison, although she is vulgar, cruel and adulterous, since she proves wise enough to live her life in a healthy and natural manner.

This bohemian lifestyle characterises the Wife of Bath as well, since she too enjoys her human condition on the basis of her own gender-specific 
instincts and needs: excessive sexuality and corporeality, vulgar verbaloutbursts, material exploitation of all her husbands and an ostentatious and extravagant attitude. She also symbolizes all the cunning tricks that a woman of the Middle Ages needed to resort to in order to survive amidst the heteronormative patriarchal dominance that prevailed in those times: "Blessed be God that I have wedded five! / Welcome the sixth whenever that he shall" (142). This is why Chaucer repeatedly presents her in a favorable light, never accusing or even making fun of her, despite her unorthodox behavior.

It is becoming evident that Chaucer advocates a natural modus vivendi and an existential philosophy situated as close as possible to Nature, to one's own soma and spiritus, and to one's deepest psychological and spiritual roots, even if this implies a certain amount of vulgarity, excessive (female) sexuality, female dominance in marriage or an easygoing attitude on moral issues. Chaucer's auctorial voice militates for the principle of naturalness as the philosophical foundation of a complete and fulfilling existence.

According to this Weltanschauung, a natural lifestyle also presupposes marrying 'naturally', that is, according to one's feelings and desires. One need not force or bend the spontaneous laws of attraction: "Men shoulde wedden after their estate, / For youth and eld are often at debate" (89). This is the Miller's firm argument at the opening of his Tale, yet it in fact hides Chaucer's similar conviction. Consequently, the poet does not blame Alison for cheating on her jealous old husband. According to Chaucer's semi-veiled argumentation, a young, vivacious damsel like Alison should follow her heart's desires: it is no surprise that she fancies a handsome man who is closer to her in age. Thus, in not doing anything abominable but merely following the dictates of nature, 
Alison is not sinful in any way. She is only surviving in an encrypted, patriarchal society. The medieval patriarchal system is one further element that Chaucer is arguing against and he therefore promotes the avant-garde Alison.

The Wife of Bath's socio-marital situation is quite different from Alison's. Since she has been married five times, her last husband, the one whom she values most, was half her age, that is, only twenty years old. Despite the age difference they were quite happy together and she has even outlived him. One might therefore inquire why the idea of same-age relationships does not apply in her case.

One reason might be the fact that the Wife of Bath is a more complex character than Alison and is able to transcend the above-mentioned relationship model. Although no longer young, she thinks, feels and acts as if she were a young lass. Although she was twice her last husband's age she was as fresh and voluptuous as a young woman, thus completely fulfilling her young husband's desires: "I was a lusty one, / And fair, and rich, and young, and well begone / For certes I am all venerian / In feeling, and my heart is martian; / Venus me gave my lust and liquorishness, / And Mars gave me my sturdy hardiness" (153). This is why Chaucer does not criticise her; far from it, he praises her.

\section{Women's Domination in Marriage}

As stated above, the common denominator for these two female characters is their natural lifestyle. Nevertheless one may detect an additional factor in the case of the Wife of Bath. Her guiding principle in life is female domination in marriage ("mastery") and she has acted accordingly in all five of her marriages. This also becomes the central theme of her Tale: what women 
desire most in marriage, namely "Women desire to have the sovereignty / As well over their husband as their love / And for to be in mastery him above" (162).

Adopting a feminist position, Chaucer never criticises or reprimands her but instead portrays her as a good-humored, lively, shrewd wife who was intelligent enough to get the maximum from each of her husbands and who knows how to enjoy marriage and life in general. Chaucer seems to be in agreement with this philosophy of life, since he never castigates any of his female personages. This can be taken as yet another argument for the view that the three pieces under discussion are feminist literature in disguise.

What stops us in our tracks here is that Chaucer was himself a married man. Why does he argue in favor of his own gender's oppression in marriage? It is by no means easy to reply to this question and to find an explanation for Chaucer's support for female domination in marriage. He was married to his wife, Philippa, for twenty-one years, until she predeceased him. No marital or sexual scandals are recorded in any documents in connection with their marriage, except for one possible sexual assault episode in 1380 involving Chaucer (Benson 1987:xxi). Therefore, although fourteenth-century marriages were hardly ever founded on love, one may still presume that Chaucer had at least a peaceful marriage, free of scandals and violence. This is at odds with the ideal of female dominance within the married couple that he promotes in The Canterbury Tales.

Of course, the apparent lack of specific sexual scandals in Chaucer's life could be politically influenced, since he was a diplomat and a prominent member of the state apparatus. Any possible blemish in his biography would 
have automatically blemished the image of his country (which he represented abroad in his role of ambassador) and the king's image as well. Chaucer worked directly for His Majesty as a tax collector and customs official.

\section{Women Placed above Men}

Another detail that indicates that these three pieces in The Canterbury Tales are feminist literature is the fact that the knight in the Wife of Bath's Tale inflicts the most horrible offence upon womankind: he commits a rape. The royal court feels such abhorrence that the king sentences the knight to death. Paradoxically, it is the representatives of the trauma-suffering gender who save him on three different occasions: first, the queen herself persuades the king to grant the knight a last chance; second, the old woman provides him with the right answer and thus saves his life; finally, the same old woman turns into a beautiful young wife, making the knight (now her wedded husband) a happily married man till his old age.

This Tale presents the most courteous praise Chaucer could ever have brought to womanhood: in this episode he presents ladies as being superior to men in terms of clemency, wisdom, willpower and in their power to bring about changes in their social and marital life. This is why the aforementioned feminist compliment/argument once again suggests Chaucer's idea of female superiority over men in marriage and in decision-making. As Benson argues, the old woman is able to perform a double transformation and improvement: firstly, she herself changes from an ugly old woman into a charming young lady, thus symbolizing that a woman "is mistress of her own destiny, able to effect her own transformation at will" (Benson 1987:11). Secondly, not only does she 
alter her own physical appearance, but she holds the power to bring about transformation on the other gender too, turning her violent rapist husband into a meek and gentle man. By acknowledging her power, Chaucer acknowledges the female power to influence and to effect changes in general, thus once again praising the opposite gender.

A further argument in favor of Chaucer's feminist auctorial position is the fact that he even presents the knight as a weaker person than his wife. Although the knight is the medieval symbol of physical, moral and spiritual strength he proves incapable of making a decision when confronted by his wife as to whether he would prefer her to be young and possibly adulterous or aged yet faithful. He lacks the moral strength to make the decision and in a humble and humiliated tone he implores his wife to choose on his behalf. Furthermore, he imposes no conditions on his acceptance of her choice, whatever that choice may be. In other words, he accepts her "mastery". As a reward, the old lady makes the right choice, thus gaining her "mastery". The two of them commence a fairy tale-like love relationship and live happily ever after.

Consequently, Chaucer is implicitly advancing one further feminist argument: if the woman governs in marriage and prevails over her husband, their marriage will be a happy union. Following the poet's argumentation, the reader may conclude that the author is in favor of this female dominance, even if it means the undermining of his own gender's freedom in marriage.

The Canterbury Tales prove to be a consistent discourse in praise of the fair sex, since in Chaucer's opinion women live their lives closer to their natural instincts and are wiser within marital life. What is nevertheless puzzling is that women's natural modus vivendi often implies mercilessness, vulgarity 
and opportunism, yet the poet seems to promote these unorthodox examples. If Chaucer was a leading political, cultural and social figure in the whole of Western Europe (Spain, Italy, France), why would he have chosen to influence his contemporary society in a negative way by promoting such questionable characters?

The second riddle that surprises the reader is the fact that Chaucer was not only a politician but a tax collector and a customs official as well. One would never expect a representative of the state apparatus to support the idea of hedonism and of an easygoing life style. Thirdly, The Canterbury Tales was written in the Late Middle Ages, a period during which women were considered to be the lawful possessions of their husbands, so ideas such as hedonism or female "mastery" were considered deeply heretical. Yet Chaucer argues in favor of them, thus contradicting the cultural and social principles of his time.

\section{Conclusions}

A possible answer to these above-mentioned riddles is the fact that Geoffrey Chaucer proves to be a revolutionary and almost a heretical writer, arguing against the patriarchal etiquette of his age. He brilliantly succeeds in portraying these anti-canonical female characters in such a way that the reader himself adopts a positive attitude towards them, despite their questionable morality. A number of questions arise in the postmodern reader's mind: do we admire these female characters because of their existential wisdom and their enviable healthy humor? In an epoch of deep patriarchal dominance they manage to find viable ways to enjoy life to the utmost, with any existential worries fading into abstraction. 
Or, on the other hand, do we appreciate them on account of their frankness and freshness? They prove to be the most zestful defenders of life, vitality and their female right to enjoy life in an age when this was considered almost impossible or indeed immoral.

One last rhetorical question derives from the relationship between the contemporary reader and Chaucer's female personages: do women of the twenty-first century have the same existential wisdom to survive in their postmodern vise and enjoy life and maintain their marriages / relationships? Do they manage to maintain the fragile balance of inner and outer happiness under the double or threefold burden of the contemporary vise of marriage motherhood - career?

\section{References:}

Benson, L. (Ed.). 1987. The Riverside Chaucer. Boston: Houghton Mifflin Company.

Blamires, A. (Ed.). 1992. Woman Defamed and Woman Defended. An Anthology of Medieval Texts. Oxford: Clarendon Press.

Chaucer, G. 2000. The Canterbury Tales and Other Poems. [Online]. Available: http://www.scribd.com/doc/53871159/The-Canterbury-Tales-and-Other-Poems-byGeoffrey-Chaucer\#download. [2013, July 31].

Hines, J. 1993. The Fabliau in English. New York: Longman. 